\title{
Nagy mennyiségú energiaital okozta jelentős QT-megnyúlás
}

\author{
Tomcsányi János dr. - Jávor Kinga dr. \\ Budai Irgalmasrendi Kórház, Kardiológia, Budapest
}

\begin{abstract}
A szerzók egy 22 éves fiatal férfi esetét ismertetik, akinél alkohollal elfogyasztott nagy dózisú energiaital hatására jelentős, tranziens QT-szakasz-megnyúlás lépett fel. Az energiaital koffeintartalma $470 \mathrm{mg}$ volt. A fiatal férfi felvételekor a QTc 580 ms volt, ami másnapra normálissá vált $(430 \mathrm{~ms})$. A szerzők az eset kapcsán felhívják a figyelmet az energiaital veszélyeire, a QT-megnyújtó hatás patomechanizmusára, ami más esetekben malignus ritmuszavart, szívmegállást okozott. A nagy dózisú energiaital alkohollal fogyasztva, illetve fizikai terhelés alatt kifejezetten veszélyes lehet, főleg olyan egyéneknél, akiknek manifeszt vagy néma hosszú-QT-szindrómájuk van. Orv. Hetil., 2015, $156(43), 1758-1760$.
\end{abstract}

Kulcsszavak: energiaital, koffein, hosszú-QT-szindróma

\section{Excessive energy drink consumption caused marked QT prolongation}

\section{Case report}

The authors report a case of a 22 -year-old man with atypical chest pain after consumption of six energy drinks (1.5 liter containing $470 \mathrm{mg}$ coffein) with vodka. On admission ECG showed marked QT/QTc prolongation (QT/QTc, $520 / 580 \mathrm{msec})$. Next day the QT/QTc returned to fully normal (QT/QTc, 360/430 msec). It was assumed that the patient had a silent long QT syndrome and that high dose of highly caffeinated energy drink triggered the (paradoxical) prolonged QT/QTc. The authors conclude that excessive energy drink intake with alcohol or during physical exercise should be avoided.

Keywords: energy drinks, caffeine, long QT syndrome

Tomcsányi, J., Jávor, K. [Excessive energy drink consumption caused marked QT prolongation. Case report]. Orv. Hetil., 2015, 156(43), 1758-1760.

(Beérkezett: 2015. augusztus 3.; elfogadva: 2015. augusztus 27.)

Az energiaitalok elterjedése az 1980-as években kezdődött és azóta növekedése exponenciálisnak tûnik [1, 2]. A százszámra létrehozott új energiaitalok koffeintartalma igen változó, 50 mg-tól az alarmírozó 505 mg-ig terjed. Hazánkban az energiaital-fogyasztás fiatalok körében nagyon elterjedt, de más korosztályokban is magasabb, mint az európai átlag $[3,4]$. Az Állami Népegészségügyi és Tisztiorvosi Szolgálat (ÁNTSZ) adatai alapján 2011 és 2014 szeptembere között 363, energiaitallal összefüggő rosszullét fordult elő, amiből 233 esetben volt szükség egészségügyi ellátásra. További riasztó adat, hogy az esetek 75\%-a 18 évnél fiatalabbak körében történik. Elgondolkodtató, hogy az ÁNTSZ kérdőíve alapján a szülők döntő többsége tud gyermekük energiaital- fogyasztásáról és mintegy harmada nem ellenzi azt [2]. Az energiaitalok nagyfokú fogyasztása mellett több esetben szívmegállást $[5,6,7]$, illetve myocardialis infarctust $[8,9,10,11]$ állapítottak meg fiatal egyéneknél.

\section{Esetismertetés}

A 22 éves férfi anamnézisében érdemi betegség nem szerepelt, családi anamnézise szintén negatív volt. Felvételét megelőző éjszaka nagy mennyiségű (6 darab) energiaitalt fogyasztott vodka kíséretében. Egyéb izgatószert negált. Panaszai reggel kezdődtek, szorító-szúró mellkasi fájdalmat, mindkét kezének zsibbadását érezte, amelyek 2-3 órán át tartottak. Az ügyeletes orvos EKG- 


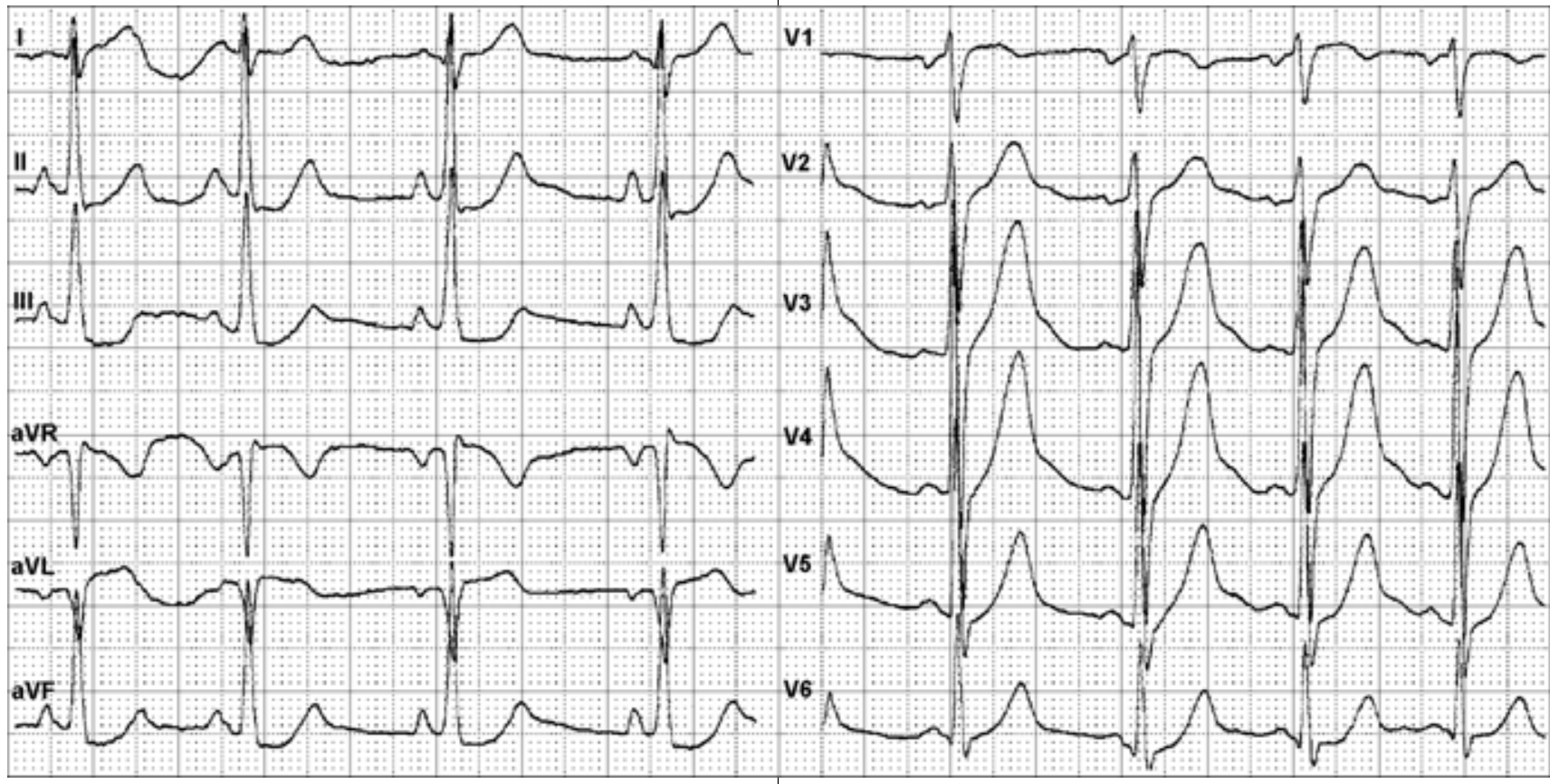

1. ábra

Felvételi EKG meredek tengelyállással. Az inferior elvezetésekben enyhén aszcendáló ST-depresszió. A standard elvezetésekben elsősorban a $\mathrm{V}_{3-4}$ elvezetésekben látható a markáns QT-megnyúlás. QT/QTc: 520/580 ms

eltéréseket észlelt, és akut coronariaszindrómát véleményezett. Clopidogrel és aszpirin adását követően a beteget coronariaórzőnkbe szállították. Felvételekor a vérnyomása $154 / 73 \mathrm{Hgmm}$, pulzusa $80 / \mathrm{min}$, keringése kompenzált volt, szívzörej nem volt hallható. Az EKG-n látható „hiperakut T-hullámokat” a kísérő hosszú QTszakasz miatt nem tartottuk ischaemiás eredetúnek (1. ábra), és ezt a normális troponin és kreatinkináz biomarkerek mellett a negatív echokardiográfia is alátámasztotta. A beteg panaszai fokozatosan megszúntek, másnapra EKG-ján a T-hullámok és a QT-idők normálissá váltak (2. ábra). Invazív vizsgálatokat nem tartottunk szükségesnek, és a beteget tanácsokkal ellátva otthonába bocsátottuk.

\section{Megbeszélés}

Fontosnak tartjuk kiemelni, hogy az energiaitalok és a koffein fogyasztásának élettani hatásai nem azonosak. Számos vizsgálat igazolta, hogy napi 3-4 adag kávé formájában a koffein fogyasztása biztonságos, és kedvező cardiovascularis hatásokkal rendelkezik [12]. Az energiaitalok a koffein mellett taurint (szulfátot tartalmazó aminosav), glükuronolaktont, ginszenget, L-karnitint és B-vitaminokat tartalmaznak, de ezek kedvezőtlen cardiovascularis hatása nem ismert.

$\mathrm{Az}$ energiaitalok ismert kedvezőtlen mellékhatásai (heves szívdobogás érzése, vérnyomás-emelkedés, krónikus alkalmazásakor elhízás, dehidráció stb.) mellett kettő, életet veszélyeztető cardiovascularis hatása lehet. A QT-szakaszt nyújtó hatása révén torsade de pontes polimorf kamrai tachycardiát és szívmegállást okozhat, továbbá a thrombocyták fokozott aggregációja és endotheldiszfunkció myocardialis infarctust válthat ki [13]. $\mathrm{Az}$ energiaitalok QT-szakaszt nyújtó hatásáról ellentmondásos a szakirodalom. Egyes vizsgálók egészséges

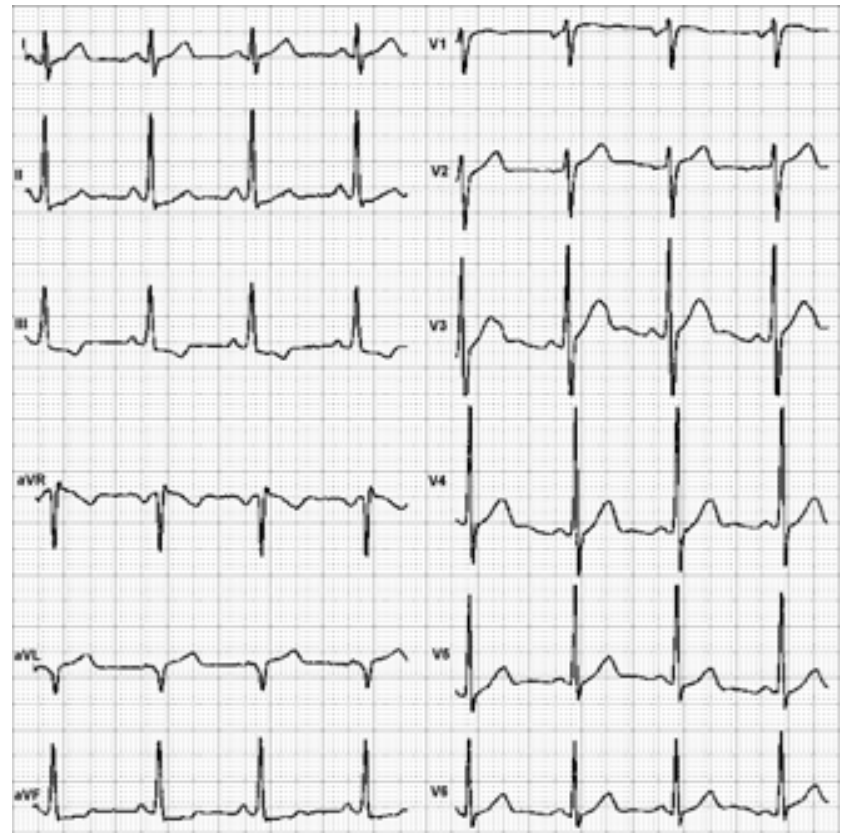

2. ábra $\quad$ Másnap készült EKG-n a III. elvezetésben enyhén deszcendáló ST-depresszió negatív T-hullámmal. A mellkasi elvezetésekben QT-megnyúlás és a magas T-hullámok megszúntek. QT/QTc: $360 / 430 \mathrm{~ms}$ 
egyéneknél nem találtak jelentős QT-megnyújtó hatást [14, 15], míg mások [6, 16] - és jelen esetben magunk is - jelentős QT-szakasz-megnyúlást észleltek. Az ellentmondás feloldása valószínúleg a koffein intracelluláris hatásával magyarázható. A koffein a szívizomsejtek cGMP receptorain keresztül aktiválja az intracelluláris cAMP-rendszert és ezzel adrenalinszerú hatást vált ki [17]. Az adrenalin paradox módon QT-megnyúlást okozhat, elsősorban l-es típusú hosszú-QT-szindrómában (LQTS). Ezért diagnosztikus tesztként is használják a latens LQTS kimutatására [18]. A silent LQTS nehezen felismerhető, ezért valószínü, hogy a veleszületett LQTS sokkal gyakoribb, mint a szakirodalomban szereplő adat (1/5000) [19]. Az energiaitalokban lévő nagy dózisú koffein (az energiaital koffeintartalma tipikusan $0,34 \mathrm{mg} / \mathrm{ml}$ ) veszélye ezeknél a silent formáknál jelentkezhet, ahol sem a megelőző klinikum, sem a családi anamnézis nem utal betegségre. Ilyen esetek nagy többségében EKG sem készül, vagy ha készülne, a hosszúQT-szindróma nem lenne felismerhető. Ezért kisszámú egészséges egyénnél a jelentős QT-megnyúlás hiánya [14, 15] nem zárja ki, hogy sok fiatal számára veszélyt jelenthet az energiaital túlzott fogyasztása.

Az energiaitalok infarktust okozó hatásában a körülbelül 14\%-os thrombocytaaggregációt fokozó hatást és kisfokú endothelfunkciót csökkentő hatást emelik ki [13], de a veszélyeztetett populáció itt nem ismert.

\section{Következtetés}

Esetünk nagy dózisú energiaital (470 mg koffein) fogyasztása következtében megjelenő silent hosszú-QTszindróma esetét mutatja be. Ennek kapcsán felhívjuk a figyelmet az energiaital túlzott fogyasztásának cardiovascularis veszélyeire. Ez annál inkább is indokolt, mert a fiatalok nagy számban és már egészen korán elkezdik fogyasztani ezeket az energiaitalokat, és ennek komoly cardiovascularis kockázata van.

Anyagi támogatás: A cikk megírása anyagi támogatásban nem részesült.

Szerzői munkamegosztás: T. J.: A cikk megszövegezése. J. K.: A beteg osztályon történő ellátása.

Érdekeltségek: A szerzőknek nincsenek érdekeltségeik.

\section{Köszönetnyilvánítás}

Köszönjük Tordas Györgynek az EKG-regisztrátumok elkészítését.

\section{Irodalom}

[1] Reissig, C. J., Strain, E. C., Griffiths, R. R.: Caffeinated energy drinks - a growing problem. Drug Alcohol Depend., 2009, 99(1-3), 1-10.

[2] Ali, F., Rebman, H., Babayan, Z., et al.: Energy drinks and their adverse health effects: a systematic review of current evidence. Postgrad. Med., 2015, 127(3), 308-322.

[3] Éló, A.: Drinking makes us sick? Risks of energy drink consumption. [Beteggé isszuk magunkat? Az energiaital-fogyasztás lopakodó veszélyei.] http://valasz.hu [Hungarian]

[4] http://www.antsz.hu [Hungarian]

[5] Berger, A. J., Alford, K.: Cardiac arrest in a young man following excess consumption of caffeinated "energy drinks". Med. J. Aust., 2009, 190(1), 41-43.

[6] Rottlaender, D., Motloch, L. J., Reda, S., et al.: Cardiac arrest due to long QT syndrome associated with excessive consumption of energy drinks. Int. J. Cardiol., 2012, 158(3), e51-e52.

[7] Jantos, R., Stein, K. M., Flechtenmacher, C., et al.: A fatal case involving a coffeine-containing fat burner. Drug Test. Anal., 2013, 5(9-10), 773-776.

[8] Benjo, A. M., Pineda, A. M., Nascimento, F. O., et al.: Left main coronary artery acute thrombosis related to energy drink intake. Circulation, 2012, 125(11), 1447-1448.

[9] Solomin, D., Borron, S. W., Watts, S. H.: STEMI associated with overuse of energy drinks. Case Rep. Emerg. Med., 2015, 2015, ID 537689.

[10] Scott, M. J., El-Hassan, M., Khan, A. A.: Myocardial infarction in a young adult following the consumption of a caffeinated energy drink. BMJ Case Rep., Published online 30 June 2011. doi: $10.1136 /$ bcr.02.2011.3854

[11] Israelit, S. H., Strizevsky, A., Raviv, B.: ST elevation myocardial infarction in a young patient after ingestion of caffeinated energy drink and ecstasy. Word J. Emerg. Med., 2012, 3(4), 305-307.

[12] Chrysant, S. G.: Coffe consumption and cardiovascular health. Am. J. Cardiol., 2015, 116(5), 818-821.

[13] Wortbley, M. I., Prabbu, A., de Sciscio, P., et al.: Detrimental effects of energy drink consumption on platelet and endothelial function. Am. J. Med., 2010, 123(2), 184-187.

[14] Shah, S. A., Lacey, C. S., Bergendabl, T., et al.: QTc interval prolongation with high dose energy drink consumption in a healthy volunteer. Int. J. Cardiol., 2014, 172(2), e336-e337.

[15] Steinke, L., Lanfear, D. E., Dhanapal, V., et al.: Effect of "energy drink" consumption on hemodynamic and electrocardiographic parameters in healthy young adults. Ann. Phamacother., 2009, 43(4), 596-602.

[16] Dufendach, K. A., Horner, J. M., Cannon, B. C., et al.: Congenital type 1 long QT syndrome unmasked by a highly caffeinated energy drink. Heart Rhythm, 2012, 9(2), 285-288.

[17] Higgins, J. P., Tuttle, T. D, Higgins, C. L.: Energy beverages: content and safety. Mayo Clin. Proc., 2010, 85(11), 1033-1041.

[18] Vyas, H., Hejlik, J., Ackerman, M. J.: Epinephrine QT stress testing in the evaluation of congenital long QT syndrome. Diagnostic accuracy of the paradoxical QT response. Circulation, 2006, 113(11), 1385-1392.

[19] Varró, A., Papp, J. G.: Low penetrance, subclinical congenital LQTS: concealed LQTS or silent LQTS? Cardiovasc. Res., 2006, 70(3), 404-406.

(Tomcsányi János dr., Budapest, Árpád fejedelem útja 7. II. em., 1023 e-mail: tomcsanyij@gmail.com) 